\title{
CIRCULATING MICRORNAS SEBAGAI NOVEL BIOMARKER UNTUK DIAGNOSIS PASIEN ACUTE ISCHEMIC STROKE: SEBUAH KAJIAN SISTEMATIS
}

\author{
Arman Caesar Ramadhan,' Nur Fatimah Azzahra Latif,, Muhammad Ainul Yaqin ${ }^{3}$
}

'Pendidikan Dokter, Fakultas Kedokteran, Universitas Hasanuddin, Makassar

2Pendidikan Dokter, Fakultas Kedokteran, Universitas Hasanuddin, Makassar

${ }_{3}$ Pendidikan Dokter, Fakultas Kedokteran, Universitas Hasanuddin, Makassar

\begin{abstract}
ABSTRAK
Korespondensi:

Arman Caesar Ramadhan

Email author:

arman.caesarramadhan@gmail.com

Riwayat Artikel

Diterima: 13 Maret 2021

Selesai revisi: 6 Juli 2021

DOI :

10.53366/jimki.v9i1.323

Pendahuluan: Acute ischemic stroke (AIS) merupakan jenis stroke dengan insidensi tertinggi utamanya pada kelompok usia lanjut. Belakangan ini, perkembangan manajemen stroke termasuk dalam hal diagnostik telah banyak memanfaatkan komponen biomolekuler karena perannya yang menjanjikan. Salah satunya adalah microRNA dari bagian keluarga small non-coding RNAs yang bisa dilepaskan ke sirkulasi dan dikenal sebagai circulating microRNA. Tujuan kajian ini untuk melakukan profiling sekaligus mengevaluasi nilai diagnostik circulating miRNA pada pasien AIS dibandingkan dengan pasien hemorrhagic stroke (HS) dan individu sehat.

Metode: Tinjauan sistematis ini mengumpulkan literatur dari PubMed, Science Direct, Clinical Trial.gov, Directory of Open Access Journal (DOAJ), dan Epistemonikos menggunakan metode standar dengan pedoman cochrane untuk tinjauan sistematis guna mengevaluasi nilai diagnostik dari circulating miRNA sebagai biomarker untuk AIS berdasarkan sensitivitas, spesifitas, dan nilai Area Under the Curve (AUC).

Pembahasan: Dari 870 studi, 15 studi sesuai dengan kriteria inklusi. Dari studi yang ditinjau, terdapat 41 jenis tipe miRNA dengan hsamiR-106b-5P dan kombinasi miR-125a-5p + miR-125b-5p + miR-143$3 p$ menjadi tipe yang terbaik untuk mendiagnosis AIS dan membedakannya dengan individu sehat. Sedangkan miR-124-3p merupakan jenis miRNA terbaik untuk membedakan AIS dan HS berdasarkan nilai sensitivitas, spesifitas, dan AUC dibandingkan miRNA lainnya yang diinklusi dalam studi ini.

Simpulan: Circulating miRNA yang diisolasi dari plasma, serum, dan darah manusia merupakan biomarker baru yang memiliki potensi untuk diagnosis awal acute ischemic stroke.
\end{abstract}

Kata Kunci: acute ischemic stroke, circulating microRNAs, diagnostik 


\title{
CIRCULATING MICRORNAS AS A NOVEL BIOMARKER FOR DIAGNOSIS OF ACUTE ISCHEMIC STROKE PATIENTS: A SYSTEMATIC REVIEW
}

\begin{abstract}
Background: Acute ischemic stroke (AIS) is the types of stroke with the highest incidence, especially in the elderly group. Recently, the development of stroke management, including in diagnostics, has widely used biomolecular components because of their promising role. One of them is microRNA from part of the family of small non-coding RNAs that can be released into the circulation and is known as circulating microRNA. The goal of this study is toprofiling as well as evaluate the diagnostic value of circulating miRNA in AIS patients, hemorrhagic stroke (HS) patients, and healthy individuals.

Methods: This systematic review collects literatures from PubMed, Science Direct, Directory of Open Access Journal (DOAJ), Clinical Trials.gov, and Epistemonikos using standardized methods by cochrane guideline for systematic review to evaluate the diagnostic value of circulating MiRNAs as biomarkers for AIS by its sensitivity, specificity, and Area Under the Curve (AUC) score.

Discussion: Out of 870 studies, 15 studies matched the inclusion criteria. From the studies reviewed, there were 41 types of miRNA with hsa-miR-106b-5P and the combination miR-125a-5p + miR-125b-5p + miR-143-3p being the best type to diagnose AIS and differentiate it from healthy individuals. Meanwhile miR-124-3p is the best type of miRNA to distinguish AIS and HS based on sensitivity, specificity, and AUC values compared to other miRNAs included in this study.

Conclusion: Circulating miRNA isolated from human plasma, serum and blood is a new biomarker that has potential for the early diagnosis of acute ischemic stroke.
\end{abstract}

Keyword:acute ischemic stroke, circulating microRNAs, diagnostic 


\section{PENDAHULUAN}

Studi ini bertujuan untuk melakukan profiling terhadap berbagai tipe microRNA (miRNA) sekaligus mengevaluasi nilai diagnostiknya pada pasien acute ischemic stroke (AIS), sehingga kelak bisa dipertimbangkan dan dikembangkan sebagai biomarker diagnostik AIS yang potensial. Stroke merupakan penyakit dengan angka kematian tertinggi kedua di dunia dan memberikan penurunan kualitas hidup yang sangat drastis bagi penderitanya ${ }^{[1]}$. Secara global, prevalensi stroke sebesar 13,7 juta orang dengan 5,5 juta kematian per tahunnya ${ }^{[2]}$. Di Indonesia, masalah stroke menjadi semakin penting untuk diperhatikan karena prevalensi stroke di Indonesia merupakan yang terbanyak di kawasan Asia. Prevalensi penderita stroke di Indonesia pada tahun 2018 sebesar $10,9 \%$ atau sekitar 713.783 orang. Dari seluruh kejadian stroke di Indonesia, prevalensi kejadian terbanyak terdapat pada lansia. Pada usia 65-74 tahun sebanyak $45,3 \%$ permil dan usia $>75$ tahun sebanyak $50,2 \%$ permil $^{[3]}$.

Penyakit stroke dibagi menjadi dua macam yaitu stroke iskemik dan stroke hemoragik. Stroke iskemik adalah jenis stroke yang paling umum terjadi dengan angka kejadian berkisar $80-85 \%$ dan risiko kematian sekitar $20 \%{ }^{[4]}$. Stroke iskemik terjadi ketika pembuluh darah di leher atau otak tersumbat ${ }^{[5]}$. Penyumbatan dapat disebabkan oleh pembentukan gumpalan di dalam pembuluh darah otak atau leher (trombosis), gumpalan dari bagian lain tubuh seperti jantung ke otak (emboli), atau penyempitan arteri yang mengarah ke otak (stenosis) $)^{[6]}$.

Belakangan ini, manajemen berbagai penyakit termasuk stroke telah banyak memanfaatkan komponen biomolekuler karena perannya yang menjanjikan dari berbagai aspek termasuk diagnostik. Salah satunya adalah microRNA (miRNA) yang merupakan nukleotida dari bagian keluarga small non-coding RNAs yang sangat banyak diekspresikan oleh sel manusia dan bisa dilepaskan ke sirkulasi yang dikenal sebagai circulating miRNA dengan stabilitasnya yang tinggi dalam darah, pola ekspresinya yang spesifik terhadap penyakit tertentu, serta pengambilan sampelnya yang mudah dengan darah dan dideteksi menggunakan reversetranscriptase polymerase chain reaction (RT-PCR) sebagai alat uji yang paling umum digunakan saat ini[7].

Sebagai biomarker diagnostik untuk AIS, miRNA sebelumnya memang telah dilaporkan berperan pada beberapa kemungkinan mekanisme yang mendasari perkembangan stroke, termasuk apoptosis seluler, peradangan saraf, dan stres oksidatifi[]. Penelitian terbaru juga memvalidasi bahwa ekspresi abnormal miRNA pada pasien dengan AIS, bisa menjadi indikator diagnostik pasien AIS ${ }^{[9]}$. Hasil ini memberikan informasi bahwa circulating miRNA berpotensi sebagai biomarker diagnosis pada pasien AIS.

Maka dari itu, kami membuat sebuah studi kajian sistematis dengan melakukan berbagai pencarian studi mengenai potensi circulating miRNA sebagai biomarker AIS menggunakan metode yang terstandarisasi oleh cochrane guideline for systematic review dengan kriteria inklusi studi yang menilai berbagai tipe circulating miRNA pada pasien acute ischemic stroke (AIS), pasien hemorrhagic stroke (HS) dan individu sehat sebagai pembanding, untuk melihat sensitivitas, spesifitas serta nilai area under the curve (AUC) sebagai indikator akurasi diagnosis dari circulating miRNA sebagai biomarker AIS.

\section{METODE}

\subsection{Pencarian Studi Literatur}

Pada kajian sistematis ini, tiga orang reviewer (A.C, N.F, dan A.Y) melakukan pencarian studi dari berbagai sumber jurnal valid seperti PubMed, Science Direct, Clinical Trials.gov, Directory of Open Access Journal (DOAJ), dan Epistemonikos pada tanggal 11 Desember 2020 mengikuti alur dan kaidah pencarian dari Preferred Reporting Items for Systematic Reviews and Meta-analyses (PRISMA) untuk mencari seluruh studi dalam rentang waktu 10 tahun terakhir yang mengindentifikasi potensi circulating miRNAs sebagai biomarker tunggal maupun kombinasi untuk diagnosis pada pasien acute ischemic stroke. Pencarian studi pada kajian sistematis 
ini menggunakan kata kunci pencarian berupa "Acute Ischemic Stroke" AND "Circulating microRNAs" AND "Diagnostic".

\subsection{Kriteria dan Penyaringan Studi}

Studi yang memenuhi syarat untuk masuk ke dalam kriteria kajian sistematis ini apabila memenuhi kriteria inklusi sebagai berikut: 1) Merupakan studi yang dipublikasi dalam 10 tahun terakhir; 2) Penelitian yang dipublikasi menggunakan bahasa Inggris; 3) Penelitian merupakan studi observasional seperti studi cohort, cross-sectional, dan case-control; 4) Pengujian pada manusia berupa pasien yang menderita acute ischemic stroke dan pasien hemorrhagic stroke atau individu sehat sebagai kontrol penelitian; 5) Pengujian studi berupa potensi circulating MiRNAs sebagai biomarker tunggal maupun kombinasi; dan 6) Luaran studi berupa nilai sensitivitas, spesifisitas, atau Area Under the Curve (AUC).

Penyaringan jurnal dilakukan oleh tiga reviewer (A.C, N.F, dan A.Y) dalam beberapa tahap.Pertama, dilakukan penyaringan judul dan abstrak studi. Studi yang tidak sesuai dengan kriteria akan dieksklusi. Studi yang sesuai dengan kriteria akan masuk ke penyaringan full text. Apabila data pada suatu studi tidak lengkap, reviewerakan menghubungi author studi tersebut melalui e-mail untuk meminta data yang diperlukan, apabila tidak ada respon dari author studi tersebut, studi akan dieksklusi. Akhirnya akan tersaring beberapa studi yang akan digunakan pada qualitative synthesis.

\subsection{Pengumpulan Data}

Data dari masing-masing studi yang akan diinklusi kemudian dikumpulkan dan dimasukkan ke dalam tabel. Data yang diambil adalah: 1) Karakteristik populasi penelitian (informasi diagnostik dan ukuran sampel); 2) Jenis miRNA yang diekspresikan (exposure); 3) Indikator pernilaian (AUC, sensitivitas, dan spesifitas); serta 4) Alat uji yang digunakan untuk mengidentifikasi biomarker. Data dikumpulkan oleh satu reviewer (N.F) kemudian disesuaikan kembali oleh dua reviewer lainnya (A.C dan A.Y). Data yang telah terkumpul nantinya akan disajikan dalam bentuk tabel.

\section{PEMBAHASAN}

\subsection{Hasil Penyaringan Studi}

Pada pencarian studi literatur dengan kata kunci "Acute Ischemic Stroke" AND "Circulating microRNAs" AND "Diagnostic" didapatkan 870 studi. Selanjutnya, didapatkan 175 studi duplikat yang dieksklusi. Kemudian reviewer membaca judul dan abstrak dari 695 studi yang tersisa untuk penyaringan selanjutnya. Pada tahap penyaringan ini, sebanyak 670 studi dieksklusi dengan alasan, seperti diterbitkan di atas 10 tahun terakhir; studi yang dipublikasi menggunakan bahasa selain bahasa Inggris; tipe publikasi tidak sesuai (publikasi protokol, buku ataupun kongres); desain penelitian tidak sesuai (case report, editor comment, journal review, systematic review dan studi metaanalysis); studi dengan populasi lain; studi dengan biomarker lain yang tidak sesuai; studi dengan pembanding lain; serta studi dengan indikator penilaian selain AUC, sensitivitas, atau spesifitas.

Hasilnya didapatkan 25 studi tersisa yang selanjutnya disaring secara full text untuk melihat kelengkapan dan akses data studi. Hasilnya ditemukan 7 studi yang tidak dapat diakses secara full text dan 3 studi yang tidak memiliki cukup data. Pada akhirnya, diperoleh 15 studi inklusi yang selanjutnya akan dilakukan qualitative synthesis dari seluruh studi tersebut. (Gambar 1). 


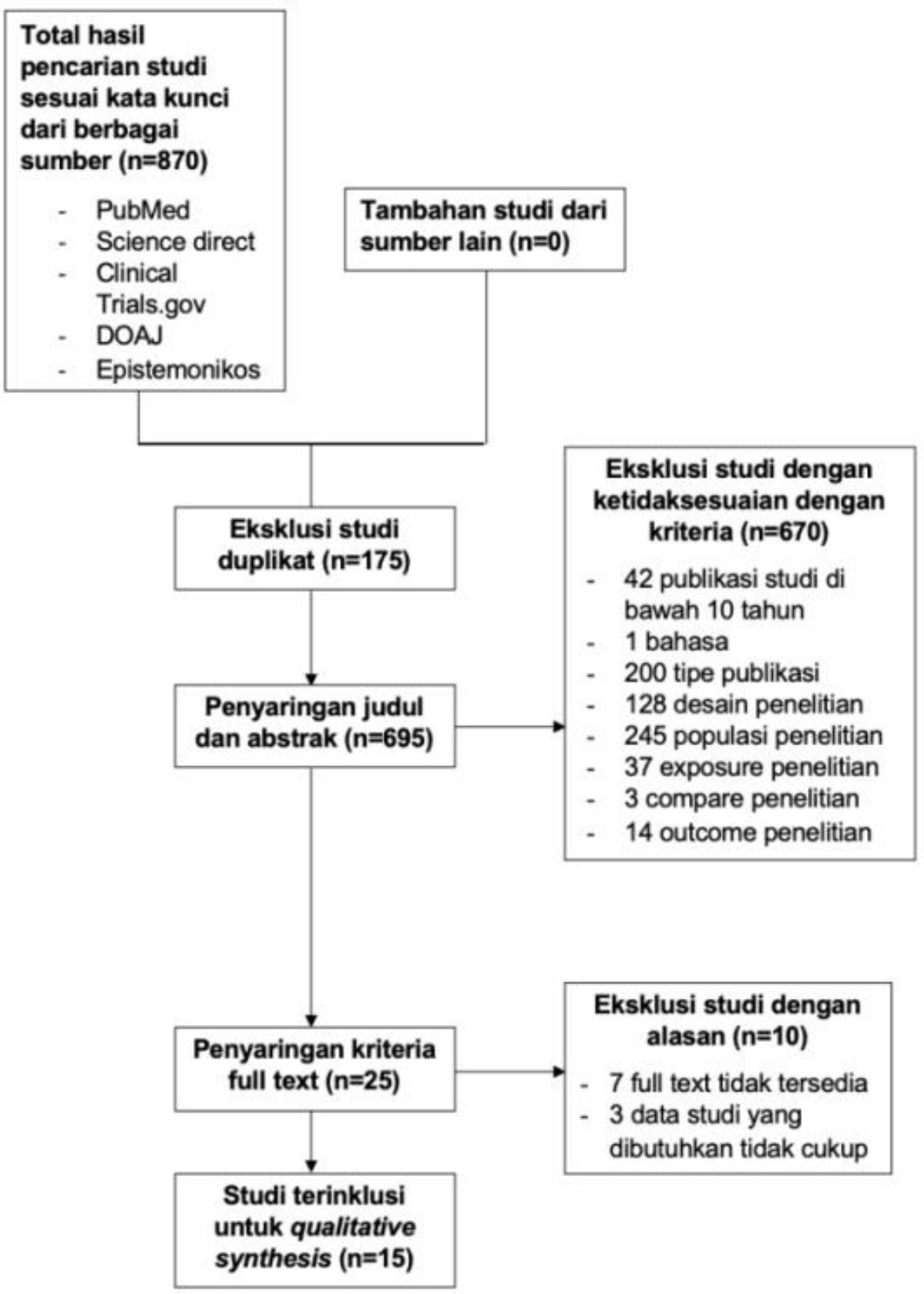

Gambar 1. Alur PRISMA dari Hasil Penyaringan Studi Inklusi

\subsection{Kriteria Studi Inklusi}

Data dari 15 studi inklusi dapat dilihat pada tabel 1. Keseluruhan jumlah populasi studi inklusi adalah 1975 sampel, diantaranya 1117 pasien acute ischemic stroke, 19 pasien hemorrhagic stroke, dan 839 individu sehat. Metode Quantitative Real-Time Polymerase Chain Reaction (qRT-PCR) digunakan pada seluruh studi untuk mendeteksi jenis dan jumlah circulating miRNA, dimana terdapat 8 studi menggunakan spesimen serum, 6 studi menggunakan spesimen plasma dan 1 studi menggunakan spesimen whole blood. Hasilnya, terdapat 41 jenis circulating miRNA yang terdeteksi meningkat maupun menurun pada pasien acute ischemic stroke dibandingkan dengan pasien kontrol. 
Tabel 1. Hasil Koleksi Data dari Kriteria Inklusi

\begin{tabular}{|c|c|c|c|c|c|c|c|c|}
\hline \multirow{2}{*}{ No } & \multirow{2}{*}{$\begin{array}{l}\text { Author } \\
\text { (Tahun) }\end{array}$} & \multirow{2}{*}{ Spesimen } & \multirow{2}{*}{$\begin{array}{l}\text { Karakteristik } \\
\text { Sampel }\end{array}$} & \multirow{2}{*}{ Exposure } & \multicolumn{3}{|l|}{ Outcome } & \multirow{2}{*}{$\begin{array}{c}\text { Alat } \\
\text { uji }\end{array}$} \\
\hline & & & & & AUC & Sen & Spe & \\
\hline \multirow{8}{*}{1} & \multirow{8}{*}{$\begin{array}{l}\text { Wang } \\
(2014)^{[10]}\end{array}$} & \multirow{8}{*}{ Plasma } & \multirow{8}{*}{$\begin{array}{l}\text { AIS (136) } \\
\text { HC (116) }\end{array}$} & $\begin{array}{c}\text { hsa-miR-106b-5P } \\
\text { MRI(-) }\end{array}$ & $0.999(95 \% \mathrm{Cl}: 0.997-0.954 ; p=.000)$ & - & - & \multirow{8}{*}{$\begin{array}{l}\text { qRT- } \\
\text { PCR }\end{array}$} \\
\hline & & & & hsa-miR-4306 MRI(-) & $0.877(95 \% \mathrm{Cl}: 0.799-0.954 ; p=.000)$ & - & - & \\
\hline & & & & hsa-miR-320e MRI(-) & 0.953 (95\% Cl: 0.913-0.994; $p=.000)$ & - & - & \\
\hline & & & & & $0.977(95 \% \mathrm{Cl}: 0.952-1.000 ; p=.000)$ & - & - & \\
\hline & & & & $\begin{array}{c}\text { hsa-miR-106b-5P } \\
\text { MRI(+) }\end{array}$ & $0.962(95 \% \mathrm{Cl}: 0.930-0.993 ; p=.000)$ & - & - & \\
\hline & & & & hsa-miR-4306 MRI(+) & $0.952(95 \% \mathrm{Cl}: 0.922-0.982 ; \mathrm{p}=.000)$ & - & - & \\
\hline & & & & hsa-miR-320e MRI(+) & $0.981(95 \% \mathrm{Cl}: 0.963-0.998 ; p=.000)$ & - & - & \\
\hline & & & & hsa-miR-320d MRI(+) & $0.987(95 \% \mathrm{Cl}: 0.972-1.000 ; p=.000)$ & - & - & \\
\hline \multirow{2}{*}{2} & \multirow{2}{*}{$\begin{array}{l}\text { Leung } \\
(2014)^{[11]}\end{array}$} & \multirow{2}{*}{ Plasma } & \multirow{2}{*}{$\begin{array}{l}\text { AIS (74) } \\
\text { HS (19) }\end{array}$} & miR-124-3p & 0.70 (95\% Cl: 0.59-0.79) & $68.4 \%$ & $71.2 \%$ & \multirow{2}{*}{$\begin{array}{l}\text { qRT } \\
\text { PCR }\end{array}$} \\
\hline & & & & $\operatorname{miR}-16$ & 0.66 (95\% Cl: 0.55-0.76) & $94.7 \%$ & $35.1 \%$ & \\
\hline \multirow{4}{*}{3.} & \multirow{4}{*}{$\begin{array}{c}\text { Wu } \\
(2015)^{[12]}\end{array}$} & \multirow{4}{*}{ Serum } & \multirow{4}{*}{$\begin{array}{l}\text { AIS (106) } \\
\text { HC (120) }\end{array}$} & $\operatorname{miR}-15 a$ & $0.698(95 \% \mathrm{Cl}: 0.559-0.837 ; \mathrm{p}=0.01)$ & - & - & \multirow{4}{*}{$\begin{array}{l}\text { qRT } \\
\text { PCR }\end{array}$} \\
\hline & & & & $\operatorname{miR}-16$ & $0.82(95 \% \mathrm{Cl}: 0.71-0.931 ; \mathrm{p}<0.001)$ & - & - & \\
\hline & & & & miR-17-5p & $0.784(95 \% \mathrm{Cl}: 0.666-0.903 ; p<0.001)$ & - & - & \\
\hline & & & & $\begin{array}{c}\text { miR-15a+miR- } \\
\text { 16+miR-17-5p }\end{array}$ & 0.845 (95\%Cl: 0.74-0.949;p< 0.001) & - & - & \\
\hline \multirow{3}{*}{4.} & \multirow{3}{*}{$\begin{array}{c}\text { Jia } \\
(2015)^{[13]}\end{array}$} & \multirow{3}{*}{ Serum } & \multirow{3}{*}{$\begin{array}{l}\text { AIS (146) } \\
\text { HC (96) }\end{array}$} & hs-CRP + miR-145 & 0.896 (95\% Cl: $0.804-0.951 ; p<0.001)$ & - & - & \multirow{3}{*}{$\begin{array}{l}\text { qRT- } \\
\text { PCR }\end{array}$} \\
\hline & & & & hs-CRP + miR-23a & 0.816 (95\% Cl: $0.726-0.887 ; p<0.001)$ & - & - & \\
\hline & & & & hs-CRP + miR-221 & 0.819 (95\% Cl: 0.738-0.892; $p<0.001)$ & - & - & \\
\hline
\end{tabular}




\begin{tabular}{|c|c|c|c|c|c|c|c|c|}
\hline \multirow{2}{*}{5.} & \multirow{2}{*}{$\begin{array}{c}\text { Peng } \\
(2015)^{[14]}\end{array}$} & \multirow{2}{*}{ Serum } & \multirow{2}{*}{$\begin{array}{l}\text { AIS (72) } \\
\text { HC (51) }\end{array}$} & let-7e & 0.86 (95\% Cl: 0.754-0.968; p=0.0091) & $82.8 \%$ & $73.4 \%$ & \multirow{2}{*}{$\begin{array}{l}\text { qRT- } \\
\text { PCR }\end{array}$} \\
\hline & & & & miR-338 & $0.63(p=0.056)$ & $71.9 \%$ & $53.2 \%$ & \\
\hline \multirow{2}{*}{6.} & \multirow{2}{*}{$\begin{array}{c}\mathrm{Ji} \\
(2016)^{[15]}\end{array}$} & \multirow{2}{*}{ Serum } & \multirow{2}{*}{$\begin{array}{l}\text { AIS (65) } \\
\text { HC (66) }\end{array}$} & $\operatorname{miR}-9$ & 0.8026 (95\% Cl: 0.7235-0.8816; $p<0.01)$ & - & - & \multirow{2}{*}{$\begin{array}{l}\text { qRT- } \\
\text { PCR }\end{array}$} \\
\hline & & & & miR-124 & $0.6976(95 \% \mathrm{Cl}: 0.6506-0.7895 ; p<0.01)$ & - & - & \\
\hline \multirow{3}{*}{7.} & \multirow{3}{*}{$\begin{array}{l}\text { Wang } \\
(2017)^{[16]}\end{array}$} & \multirow{3}{*}{ Serum } & \multirow{3}{*}{$\begin{array}{l}\text { AIS (78) } \\
\text { HC (39) }\end{array}$} & miRNA-221-3p & 0.8106 (95\% Cl: 0.7252-0.8960; $p<0.001)$ & - & - & \multirow{3}{*}{$\begin{array}{l}\text { qRT } \\
\text { PCF }\end{array}$} \\
\hline & & & & miRNA-382-5p & 0.7483 (95\% Cl: $0.6300-0.8655 ; p<0.001)$ & - & - & \\
\hline & & & & miRNA-4271 & 0.6317 (95\% Cl: 0.5127-0.7508; $p=0.066)$ & - & - & \\
\hline 8. & $\begin{array}{c}\text { Tiedt } \\
(2017)^{[17]}\end{array}$ & Plasma & $\begin{array}{l}\text { AIS (20) } \\
\text { HC (20) }\end{array}$ & $\begin{array}{c}\text { miR-125a-5p + miR- } \\
125 b-5 p+\text { miR-143-3p }\end{array}$ & 0.93 & $97.5 \%$ & $65 \%$ & $\begin{array}{l}\text { qRT- } \\
\text { PCR }\end{array}$ \\
\hline \multirow{6}{*}{9.} & \multirow{6}{*}{$\underset{(2017)^{[18]}}{\operatorname{Jin}}$} & \multirow{6}{*}{ Plasma } & \multirow{6}{*}{$\begin{array}{l}\text { AIS (10) } \\
\text { HC (10) }\end{array}$} & miR-126 & $0.654(95 \% \mathrm{Cl} 0.580-0.728)$ & & & \multirow{6}{*}{$\begin{array}{l}\text { qRT- } \\
\text { PCR }\end{array}$} \\
\hline & & & & miR-130a & $0.642(95 \% \mathrm{Cl} 0.568-0.175)$ & & & \\
\hline & & & & miR- 222 & $0.584(95 \% \mathrm{Cl} 0.508-0.661)$ & - & - & \\
\hline & & & & $\operatorname{miR}-218$ & $0.624(95 \% \mathrm{Cl} 0.549-0.699)$ & & & \\
\hline & & & & miR-185 & $0.601(95 \% \mathrm{Cl} 0.525-0.676)$ & & & \\
\hline & & & & $\begin{array}{c}\text { miR-126 + miR-130a }+ \\
\text { miR- } 222+\text { miR-218 + } \\
\text { miR-185 }\end{array}$ & $(0.767(95 \%$ Cl 0.705-0.829) & $87,7 \%$ & $54,5 \%$ & \\
\hline 10. & $\begin{array}{l}\text { Wang } \\
(2018)^{[19]}\end{array}$ & Plasma & $\begin{array}{l}\text { AIS (65) } \\
\text { HC (24) }\end{array}$ & miRNA-30a-5p & $0.438(95 \% \mathrm{Cl} 0.240-0.635, p=0.516)$ & - & - & $\begin{array}{l}\text { qRT- } \\
\text { PCR }\end{array}$ \\
\hline 11. & $\begin{array}{l}\text { Chen et al } \\
(2018)^{[20]}\end{array}$ & Serum & $\begin{array}{l}\text { AIS (30) } \\
\text { HC (30) }\end{array}$ & $\operatorname{miR}-146 b$ & $0.776(95 \% \mathrm{Cl} 0.628-0.813, \mathrm{p}<0.001)$ & - & - & $\begin{array}{l}\text { qRT- } \\
\text { PCR }\end{array}$ \\
\hline \multirow{2}{*}{12.} & \multirow{2}{*}{$\begin{array}{c}\mathrm{Li} \\
\text { et }(2018)^{[9]}\end{array}$} & \multirow{2}{*}{ Darah } & \multirow{2}{*}{$\begin{array}{l}\text { AIS (40) } \\
\text { HC (27) }\end{array}$} & \multirow{2}{*}{$\mathrm{miR}-424$} & $0.652(95 \% \mathrm{Cl} 0.527-0.777, \mathrm{p}=0.027)$ & 0.600 & 0.900 & \multirow{2}{*}{$\begin{array}{l}\text { qRT- } \\
\text { PCR }\end{array}$} \\
\hline & & & & & $0.637(95 \% \mathrm{Cl} 0.512-0.762, p=0.045)$ & 0.600 & 0.733 & \\
\hline
\end{tabular}




\begin{tabular}{|c|c|c|c|c|c|c|c|c|}
\hline \multirow{6}{*}{13.} & \multirow{6}{*}{$\begin{array}{l}\text { Jin et } \\
(2018)^{[21]}\end{array}$} & \multirow{6}{*}{ Plasma } & \multirow{6}{*}{$\begin{array}{l}\text { AIS (148) } \\
\text { HC (148) }\end{array}$} & miR-126 & 0.665 (95\% Cl 0.602-0.728) & - & - & \multirow{6}{*}{$\begin{array}{l}\text { qRT- } \\
\text { PCR }\end{array}$} \\
\hline & & & & miR-130a & $0.619(95 \% \mathrm{Cl} 0.556-0.683)$ & - & - & \\
\hline & & & & miR-222 & $0.629(95 \%$ Cl $0.566-0.692$ & - & - & \\
\hline & & & & miR-218 & $0.685(95 \%$ Cl $0.625-0.746)$ & - & - & \\
\hline & & & & miR- 185 & $0.633(95 \% \mathrm{Cl} 0.570-0.696)$ & - & - & \\
\hline & & & & $\begin{array}{c}\text { miR-126 + miR-130a }+ \\
\text { miR-222 + miR-218 } \\
\text { miR- } 185\end{array}$ & $0.840(95 \% \mathrm{Cl} 0.795-0.885)$ & $83.8 \%$ & $69.6 \%$ & \\
\hline \multirow[t]{2}{*}{14.} & \multirow[t]{2}{*}{$\begin{array}{l}\text { Zhou } \\
(2018)^{[22]}\end{array}$} & \multirow[t]{2}{*}{ Serum } & \multirow[t]{2}{*}{$\begin{array}{l}\text { AIS (50) } \\
\text { HC (50) }\end{array}$} & $\mathrm{miR}-134$ & $0.834(95 \% \mathrm{Cl}, 0.88-0.97)$ & $75.3 \%$ & $72.8 \%$ & \multirow[t]{2}{*}{$\begin{array}{l}\text { qRT- } \\
\text { PCR }\end{array}$} \\
\hline & & & & miR-148b-3p & 0.6647 (95\% Cl: $0.4895-0.8399, p<0.05)$ & - & - & \\
\hline \multirow{6}{*}{15.} & \multirow{6}{*}{$\begin{array}{l}\text { Cheng et } \\
\text { al } \\
(2018)^{[23]}\end{array}$} & \multirow{6}{*}{ Serum } & & $\operatorname{miR}-151 b$ & $0.6852(95 \% \mathrm{Cl}: 0.5412-0.8291, \mathrm{p}<0.05)$ & - & - & \multirow{6}{*}{$\begin{array}{l}\text { qRT- } \\
\text { PCR }\end{array}$} \\
\hline & & & & miR-27b-3p & $0.6657(95 \% \mathrm{Cl}: 0.5306-0.8008, \mathrm{p}<0.05)$ & - & - & \\
\hline & & & AIS (77) & $\begin{array}{l}\text { miR-148b + miR-27b- } \\
3 p\end{array}$ & $\begin{array}{c}0.8103 \text { (95\% Cl: } 0.7006-0.9199, \mathrm{p}< \\
0.001)\end{array}$ & 0.6719 & 0.9286 & \\
\hline & & & $\mathrm{HC}(42)$ & $m i R-148 b+m i R-151 b$ & $0.7266(95 \% \mathrm{Cl}: 0.5856-0.8675, p<0.05)$ & 0.6563 & 0.9167 & \\
\hline & & & & $\begin{array}{l}m i R-151 b+\operatorname{miR}-27 b- \\
3 p\end{array}$ & 0.7143 (95\% Cl: $0.5763-0.8522, p<0.01)$ & 0.2714 & 0.9333 & \\
\hline & & & & $\begin{array}{c}m i R-148 b-3 p+m i R- \\
151 b+m i R-27 b-3 p\end{array}$ & $0.7712(95 \% \mathrm{Cl}: 0.6520-0.8903, p<0.01)$ & 0.5238 & 0.9167 & \\
\hline
\end{tabular}

Keterangan:AIS:acute ischemic stroke; HC:healthy control; HS:hemorrhagic stroke; qRT-PCR: quantitative real-time polymerase chain reaction 


\subsection{Potensi Biomarker Circulating miRNA untuk Membedakan Pasien Acute Ischemic Stroke dan Individu Sehat}

Circulating miRNA berpotensi untuk membedakan pasien AIS dengan individu sehat menurut kadar ekspresinya. Dalam kajian sistematis ini, kami menemukan 14 studi yang membandingkan kadar miRNA penderita AIS dengan individu sehat. Total miRNA yang diteliti sebanyak 29 jenis untuk miRNA tunggal dan 11 jenis untuk miRNA kombinasi. Isolasi miRNA dari serum, plasma, dan darah penderita AIS dapat menghasilkan nilai diagnostik AIS yang beragam dan cukup tinggi pada berbagai studi. Misalnya untuk penggunaan miRNA tunggal hsa-miR106b-5P, miR-16, dan let 7 masingmasing memiliki nilai AUC sebesar $0,999,0,82$, dan $0,86^{[10,12,14]}$ dengan hasil yang menunjukkan hsa-miR-106b5P sebagai miRNA tunggal terbaik dibanding seluruh miRNA pada studi inklusi.

Beberapa studi inklusi juga menemukan nilai diagnostik AUC miRNA lebih baik apabila menggunakan kombinasi dari beberapa miRNA dibandingkan penggunaan miRNA tunggal[ ${ }^{[12,18,21,23]}$. Misalnya miR$15 a+m i R-16+m i R-17-5 p \quad$ sebagai kombinasi miRNA dengan nilai akurasi AUC terbaik yaitu sebesar 0,845 dibanding kombinasi lainnya yang memiliki pembanding miRNA tunggal[ ${ }^{[14]}$. Akan tetapi, untuk nilai akurasi AUC tertinggi sebenarnya dimiliki oleh kombinasi miR-125a-5p + miR-125b-5p $+\quad m i R-143-3 p^{[17]}$, hanya saja kelemahannya dalam studi tersebut tidak menampilkan nilai AUC miRNA tunggalnya sebagai pembanding. Walaupun demikian, dengan adanya empat studi sebelumnya yang menunjukkan bahwa kombinasi miRNA bisa memberikan nilai diagnostik yang lebih baik dibanding miRNA tunggalnya, kita bisa menarik hipotesis bahwa miR$125 a-5 p+m i R-125 b-5 p+m i R-143-3 p$ sebagai kombinasi miRNA dengan akurasi diagnostik terbaik sepertinya juga memiliki nilai AUC yang lebih baik dibandingkan miRNA tunggalnya sehingga bisa dipertimbangkan sebagai pilihan kombinasi miRNA untuk biomarker diagnosis AIS. Pada studi
Wang et al[10] yang memiliki nilai diagnostik miRNA tunggal terbaik, sebetulnya juga memiliki kelemahan dalam desain sampelnya karena tidak menilai akurasi diagnostik miRNA yang mereka usulkan dalam bentuk kombinasi, sehingga walaupun hsa-miR106b-5P sebagai miRNA tunggal memiliki nilai diagnostik lebih baik dibandingkan keseluruhan jenis miRNA dalam studi yang terinklusi, namun karena dalam pembagian kelompok sampelnya tidak ada dalam bentuk kombinasi, jadi hipotesis yang bisa juga kita tarik bahwa hsa-miR-106b-5P apabila dikombinasikan dengan miRNA lain akan memiliki nilai diagnostik yang lebih tinggi.

Grafik pembuktian mengenai hal tersebut terlihat pada penelitian Wang et al ${ }^{[10]}$ yang memiliki nilai akurasi diagnostik miRNA tunggal terbaik dan pada penelitian Tiedt et al. yang memiliki nilai akurasi diagnostik kombinasi miRNA terbaik (Grafik 1).
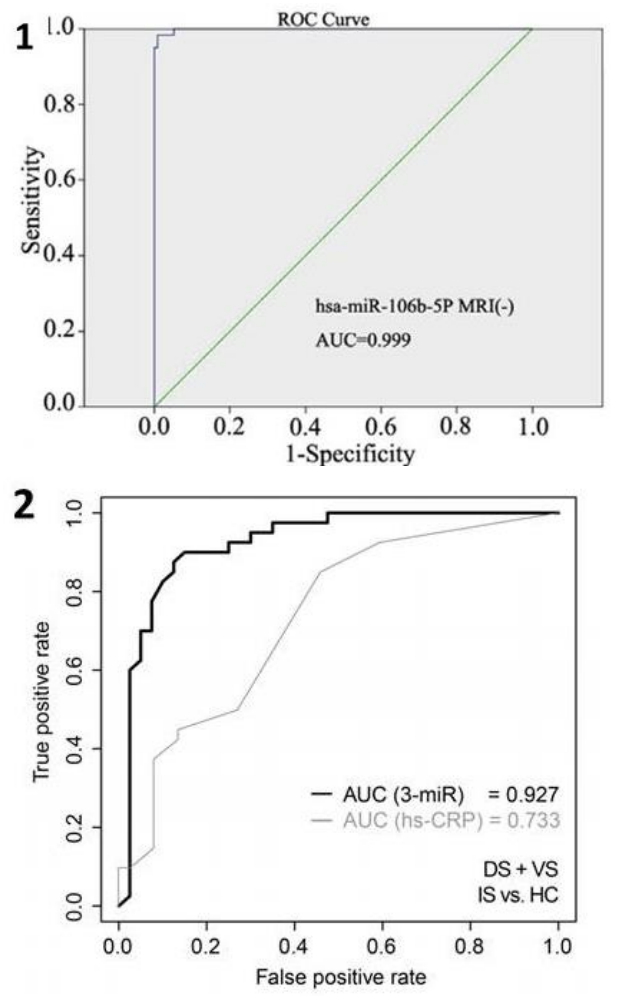

Grafik 1.Efektivitas diagnostik miRNA untuk membedakan pasien AIS dengan pasien normal. (1) Grafik diagnostik hsamiR-106b-5P sebagai miRNA tunggal;

(2) Grafik diagnostik miR-125a-5p + 
miR-125b-5p + miR-143-3p sebagai kombinasi miRNA ${ }^{[10]}$

Hasil ini memberikan gambaran bahwa hsa-miR-106b-5P dan kombinasi $m i R-125 a-5 p+m i R-125 b-5 p+m i R-143-$ $3 p$ dapat direkomendasikan sebagai subtipe miRNA paling ideal yang telah diteliti pada berbagai studi inklusi sebagai biomarker pasien AIS, guna membedakannya dengan individu sehat. Berbagai temuan ini juga memberikan tanda bahwa circulating MiRNA, baik tunggal maupun kombinasi, dalam sampel plasma, serum dan darah dapat digunakan sebagai biomarker yang memiliki nilai diagnostik sangat baik dalam mendiagnosis pasien AIS.

\subsection{Potensi Biomarker Circulating miRNA untuk Membedakan Pasien Acute Ischemic Stroke dan Pasien Hemorrhagic Stroke}

Setelah terbukti bahwa miRNA ternyata punya potensi menjanjikan dalam mendiagnosis pasien AIS dan membedakannya dengan individu sehat, selanjutnya perlu juga dilakukan analisis dalam menilai potensi miRNA untuk membedakan pasien AIS dengan pasien HS sebagai diagnosis banding utamanya untuk menghindari misdiagnosis karena akan mempengaruhi tata laksana ke depannya.

Berdasarkan studi yang terinklusi, didapatkan satu studi oleh Leung et $a^{[11]}$ yang membandingkan akurasi diagnostik miRNA untuk membedakan pasien AIS dan HS. Subtipe miRNA yang diusulkan ada dua yaitu miR-124-3p dan miR-16 dengan menggunakan plasma sebagai sampel penelitian. Untuk nilai akurasi diagnostiknya, miR-124-3p memiliki sensitivitas $68,4 \%$, spesifitas $71,2 \%$ dan AUC 0,70 sedangkan untuk miR-16 memiliki sensitivitas $94,7 \%$, spesifitas $35,1 \%$, dan AUC 0,66. Sehingga secara keseluruhan, miR-124-3p memiliki akurasi diagnostik yang lebih baik untuk membedakan pasien AIS dengan HS. Untuk teknik diskriminasi pasien AIS dan HS dinilai berdasarkan konsentrasi miR-124-3p dan miR-16 dalam plasma (Grafik 2).

Hasil ini menunjukkan bahwa miRNA bukan hanya digunakan sebagai biomarker untuk membedakan pasien
AIS dan individu sehat tapi juga mampu menjadi biomarker untuk membedakan antara pasien acute ischemic stroke dan pasien hemorrhagic stroke.

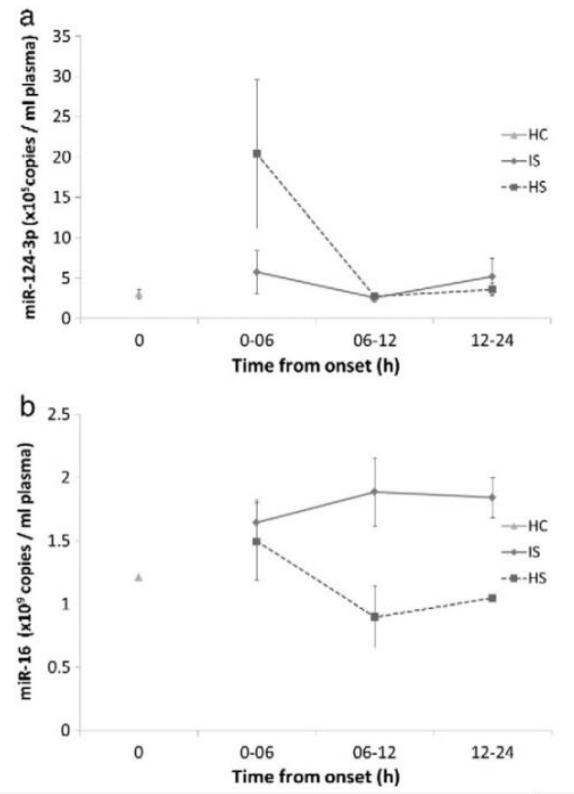

Grafik 2. Perubahan konsentrasi miR124-3p dan miR-16 dalam plasma sebagai indikator diskrimasi pasien AIS dan $\mathrm{HS}^{[11]}$

\subsection{Mekanisme Circulating miRNA sebagai Biomarker Acute Ischemic Stroke}

Patofisiologi acute ischemic stroke berhubungan dengan proses inflamasi, proses pembekuan darah, dan aktivasi platelet. Dalam proses tromboemboli pada stroke, terjadi aktivasi trombosit untuk mengatur kaskade inflamasi dengan memicu pembentukan dan pertumbuhan trombus, mengaktifkan leukosit, dan potensiasi cedera endotel serebral[24]. MicroRNA (miRNA) sendiri merupakan sekelompok non-codingRNA yang meregulasi ekspresi berbagai gen dan berperan dalam berbagai proses biologis termasuk proses inflamasi dan respon imunitas ${ }^{[25]}$. Circulating miRNA dapat dikaitkan dengan ekspresi dalam sistem saraf dan pelepasannya dari sel yang mengalami kerusakan sehingga menyebabkan peningkatan ekspresi miRNA yang bersirkulasi[26]. Apoptosis, neuroinflamasi, stres oksidatif, gangguan sawar darah otak, dan edema serebri merupakan mekanisme yang mendasari regulasi miRNA pada pasien 
acute ischemic stroke, mekanisme tersebut kemudian memicu pelepasan miRNA ke ruang ekstraseluler ${ }^{[29]}$. Diagram skematik terlihat pada Gambar 2.

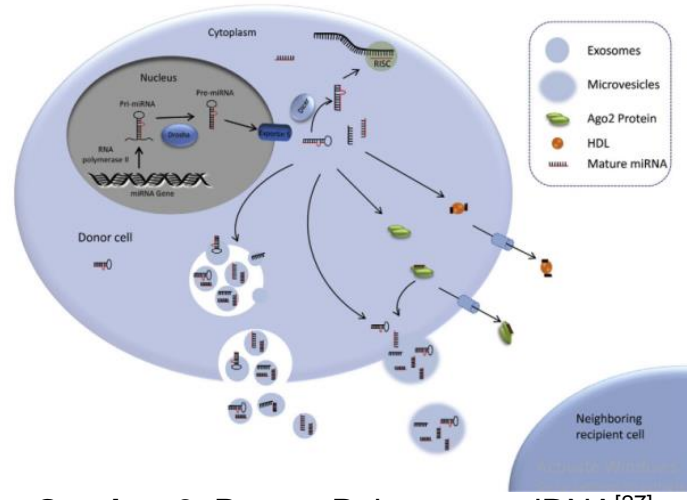

Gambar 2. Proses Pelepasan miRNA ${ }^{[27]}$

Pelepasan miRNA ke ruang ekstraseluler dapat melalui exosomes, microvesicles, apoptotic bodies, high density lipoprotein (HDL), dan AGOprotein complex. 1) Exosomes terbentuk dari invaginasi membran yang disebut endosome yang berisi miRNA yang telah matur, yang nantinya akan fusi dengan membran plasma dan dilepaskan ke ekstrasel. 2) Microvesicle yang berisi miRNA yang matur dilepaskan secara langsung ke luar sel melalui outward budding dari membran plasma. 3) Apoptotic bodies merupakan vesikel yang terpapar phosphatidylserine (PS) akibat dari proses apoptosis sel, apoptotic bodies memuat miRNA. 4) HDL berikatan dengan miRNA membentuk kompleks miRNA-HDL yang akan dikeluarkan dari sel melalui proses eksositosis. 5) AGO protein berikatan dengan miRNA membentuk miRNA-induced silencing complex (miRISC), yang akan dilepaskan ke eksrasel[28]. Mekanisme pelepasan tersebut yang menyebabkan miRNA dapat ditemukan bersirkulasi di luar sel.Circulating miRNA dapat dideteksi di beberapa cairan tubuh seperti plasma, serum, urin, dan cairan serebrospinal dengan sangat stabil, menunjukkan potensinya sebagai penanda diagnostik untuk berbagai penyakit termasuk $\mathrm{AIS}^{[29]}$.

\section{KESIMPULAN}

Sebagai kesimpulan, circulating miRNA merupakan biomarker baru yang memiliki potensi untuk diagnosis awal acute ischemic stroke. Dari kajian sistematis ini terdapat 41 jenis miRNA yang ditemukan dan berpotensi sebagai biomarker diagnostik dengan hsa-miR106b-5P dan kombinasi miR-125a-5p + miR-125b-5p + miR-143-3p sebagai jenis miRNA yang paling baik dalam mendiagnosis AIS dan membedakannya dengan individu sehat. Sedangkan miR124-3p merupakan jenis miRNA yang paling baik menjadi biomarker untuk membedakan acute ischemic stroke dan hemorrhagic stroke berdasarkan nilai sensitivitas, spesifitas, dan AUC dibandingkan miRNA lainnya yang diinklusi dalam studi ini.

\section{DAFTAR PUSTAKA}

1. Yamashita $T$, Abe K. Recent progress in therapeutic strategies for ischemic stroke. Cell Transplant. 2016;25(5):893-8.

2. World Stroke Organization. WSO global stroke fact sheet. 2019.

3. Balitbang Kemenkes RI. Riset Kesehatan Dasar; RISKESDAS. Jakarta: Balitbang Kemenkes RI. 2018.

4. Rohmatul, L. Hubungan Karakteristik Penderita Dan Hipertensi Dengan Kejadian Stroke Iskemik. Surabaya 2017.

5. Wallace, J. B. Researchers document troubling rise in strokes in young adults, starting at age 25 . The Washington Post. 2016.

6. National Institute of Neurological Disorders and Stroke. Brain basics: Preventing stroke. 2016. 8. Xing, C., Arai, K., L.

7. Hiam D, Lamon S. Circulating microRNAs: let's not waste the potential. Am J Physiol Cell Physiol 2020;2:C313-5.

8. Lu M, Dong X, Zhang Z, Li W, Khoshnam SE. Non-coding RNAs in Ischemic Stroke: Roles in the Neuroinflammation and Cell Death. Neurotox Res. 2020;38(3):564-78.

9. Li G, Ma Q, Wang R, Fan Z, Tao Z, Liu $P$, et al. Diagnostic and immunosuppressive potential of elevated MiR-424 levels in circulating immune cells of ischemic stroke patients. Aging Dis. 2018;9(2):172-781. 
10. Wang W, Sun G, Zhang L, Shi L, Zeng $Y$. Circulating MicroRNAs as novel potential biomarkers for early diagnosis of acute stroke in humans. J Stroke Cerebrovasc Dis. 2014;23(10):2607-13.

11. Leung LY, Chan CPY, Leung YK, Jiang $\mathrm{HL}$, Abrigo JM, Wang DF, et al. Comparison of miR-124-3p and miR-16 for early diagnosis of hemorrhagic and ischemic stroke. Clin Chim Acta. 2014;433:139-44.

12. Wu J, Du K, Lu X. Elevated expressions of serum miR-15a, miR-16, and. 2015;8(11):21071-9.

13. Jia $L$, Hao $F$, Wang $W, Q u ~ Y$. Circulating miR-145 is associated with plasma high-sensitivity Creactive protein in acute ischemic stroke patients. Cell Biochem Funct. 2015;33(5):314-9.

14. Peng G, Yuan $Y$, Wu S, He F, Hu $Y$, Luo B. MicroRNA let-7e is a Potential Circulating Biomarker of Acute Stage Ischemic Stroke. Transl Stroke Res. 2015;6(6):43745.

15. Ji Q, Ji Y, Peng J, Zhou X, Chen X, Zhao $H$, et al. Increased brainspecific MiR-9 and MiR-124 in the serum exosomes of acute ischemic stroke patients. PLoS One. 2016;11(9):1-14.

16. Wang $Y$, Ma Z, Kan P, Zhang B. The Diagnostic Value of Serum miRNA-221-3p, miRNA-382-5p, and miRNA-4271 in Ischemic Stroke. J Stroke Cerebrovasc Dis . 2017;26(5):1055-60.

17. Tiedt $S$, Prestel M, Malik R, Schieferdecker $N$, Duering $M$, Kautzky V, et al. RNA-seq identifies circulating MIR-125a-5p, MIR-125b$5 p$, and MIR-143-3p as potential biomarkers for acute ischemic stroke. Circ Res. 2017;121(8):97080.

18. Jin F, Xing J. Circulating proangiogenic and anti-angiogenic microRNA expressions in patients with acute ischemic stroke and their association with disease severity. Neurol Sci. 2017;38(11):2015-23.

19. Wang W, Li D Bin, Li RY, Zhou X, Yu DJ, Lan XY, et al. Diagnosis of hyperacute and acute ischaemic stroke: The potential utility of exosomal microRNA-21-5p and
MicroRNA-30a-5p. Cerebrovasc Dis. 2018;45(5-6):204-12.

20. Chen Z, Wang K, Huang J, Zheng G, Lv Y, Luo N, et al. Upregulated Serum MiR-146b Serves as a Biomarker for Acute Ischemic Stroke. Cell Physiol Biochem. 2018;45(1):397-405.

21. Jin F, Xing J. Circulating miR-126 and miR-130a levels correlate with lower disease risk, disease severity, and reduced inflammatory cytokine levels in acute ischemic stroke patients. Neurol Sci. 2018;39(10):1757-65.

22. Zhou J, Chen L, Chen B, Huang S, Zeng $\mathrm{C}, \mathrm{Wu} \mathrm{H}$, et al. Increased serum exosomal miR-134 expression in the acute ischemic stroke patients. BMC Neurol. 2018;18(1):1-9.

23. Cheng X, Kan $P$, Ma Z, Wang $Y$, Song $W$, Huang $C$, et al. Exploring the potential value of miR-148b-3p, miR-151b and miR-27b-3p as biomarkers in acute ischemic stroke. Biosci Rep. 2018;38(6).

24. De Rosa S, Eposito F, Carella C, Strangio A, Ammirati G, Sabatino J, et al. Transcoronary concentration gradients of circulating microRNAs in heart failure. Eur $\mathrm{J}$ Heart Fail. 2018;20(6):1000-10.

25. Hayes J, Peruzzi PP, Lawler S. MicroRNAs in cancer: Biomarkers, functions and therapy. Trends Mol Med . 2014;20(8):460-9.

26. Mayr M, Zampetaki A, Kiechl S. MicroRNA biomarkers for failing hearts? Eur Heart J. 2013;34(36):2782-3.

27. Xu W, Gao L, Zheng J, Li T, Shao $A$, Reis C, et al. The Roles of MicroRNAs in Stroke: Possible Therapeutic Targets. Cell Transplant. 2018;27(12):1778-88.

28. Sohel MH. Extracellular/Circulating MicroRNAs: Release Mechanisms, Functions and Challenges. Achiev Life Sci. 2016;10(2):175-86.

29. Ghelani HS, Rachchh MA, Gokani $\mathrm{RH}$. MicroRNAs as newer therapeutic targets: A big hope from a tiny player. $\mathrm{J}$ Pharmacol Pharmacother. 2012;3(3):217-27. 